\title{
Evaluation of tolerance to Phytophthora capsici-the causal agent of foot rot disease in black pepper
}

\author{
Anh T. Ton*, Tram T. N. To, Thanh T. L. Bien, Phong V. Nguyen, \& Don D. Le \\ Department of Biotechnology, Nong Lam University, Ho Chi Minh City, Vietnam
}

ARTICLE INFO
Research Paper
Received: April 10, 2018
Revised: May 18, 2018
Accepted: May 30, 2018
Keywords
Black pepper
Infection
Phytophthora capsici
Tolerance
*Corresponding author
Ton Trang Anh
Email: tontranganh@hcmuaf.edu.vn

\begin{abstract}
Vietnam is the leading black pepper export country in the world. However, the production of pepper may be affected by natural disasters, pests such as Phytophthora capsici. The Phytophthora capsici disease has caused a significant decline in pepper yields. The desease is characterized with a high mortality rate (up to 100\%) and rapid outbreak and thus is very challenging to control. In the present study, eight strains of $P$. capsici were isolated from 100 samples of leaf, stem, root and soil that were collected from pepper-growing areas of Dong Nai, Binh Duong and Ba Ria - Vung Tau provinces. These isolates' straits had capacity to cause foot rot on pepper leaf after two days of inoculation. Among them, the isolates with the highest pathogenicity are BR-L1, DN-D1 and DN-D2. In order to determine the resistance level to $P$. capsici of commonly grown pepper varieties (Vinh Linh, Se, Xanh, Trau and Kuching), the pepper leaves wewe in vitro infected with $P$. capsici BR-L1 spores in laboratory and greenhouse conditions. Trau variety showed the highest resistance level to $P$. capsici with the as indicated by $(P<0.01)$ disease ratio $(74.1 \%)$ and disease index $(73.7 \%)$ after 6 days in laboratory condition and the corresponding numbers of $17.3 \%$ and $15.8 \%$ after 12 days in greenhouse condition.
\end{abstract}

Cited as: Ton, A. T., To, T. T. N., Bien, T. T. L., Nguyen, P. V., \& Le, D. D. (2019). Evaluation of tolerance to Phytophthora capsici-the causal agent of foot rot disease in black pepper. The Journal of Agriculture and Development 18(1), 26-34. 


\section{Đánh giá khả năng chống chịu bệnh chết nhanh (Phytophthora capsici) của một số giống hồ tiều trong điều kiện thí nghiệm}

Tôn Trang Ánh*, Tô Thị Nhã Trầm, Biện Thị Lan Thanh, Nguyễn Vũ Phong \& Lê Đình Đôn Bộ Môn Công Nghệ Sinh Học, Trường Đại Học Nông Lâm TP. Hồ Chí Minh, TP. Hồ Chí Minh

\section{THÔNG TIN BÀI BÁO}

Bài báo khoa học

Ngày nhận: 10/04/2018

Ngày chỉnh sửa: $18 / 05 / 2018$

Ngày chấp nhận: 30/05/2018

\section{Từ khóa \\ Chống chịu \\ Hồ tiêu \\ Lây nhiễm \\ Phytophthora capsici}

\section{*Tác giả liên hệ}

Tôn Trang Ánh

Email: tontranganh@hcmuaf.edu.vn

\section{TÓM TẮT}

Việt Nam hiện là nước xuất khẩu hồ tiêu đứng đầu trên thế giới. Tuy nhiên, ngành sản xuất hồ tiêu trong nước đang đứng trước nhiều thách thức do thiên tai, sâu bệnh. Trong đó, bệnh chết nhanh do Phytophthora capsici là bệnh gây thiệt hại nặng cho ngành trồng tiêu. Tại nhiều vùng chuyên canh hồ tiêu, bệnh lây lan nhanh, thường tạo thành ổ dịch, làm giảm đáng kể diện tích canh tác và khó tái canh hồ tiêu trên nền đất cũ. Từ 100 mẫu rễ, thân và lá cây hồ tiêu có biểu hiện bệnh chết nhanh và đất xung quanh cây bệnh, đã phân lập được 08 dòng $P$. capsici. Tất cả các dòng $P$. capsici phân lập đều có khả năng gây bệnh chết nhanh trên lá hồ tiêu sau hai ngày lây nhiễm trong điều kiện thí nghiệm. Trong đó, ba dòng thể hiện độc tính gây bệnh mạnh nhất so với các dòng còn lại là BR-L1, ĐN-Đ1 và ĐN-Đ2. Khả năng chống chịu bệnh do $P$. capsici của các giống hồ tiêu được trồng phổ biến tại Việt Nam gồm Vĩnh Linh, Sẻ, Xanh, Trâu và Kuching được khảo sát trong điều kiện phòng thí nghiệm và nhà lưới. Kết quả, giống tiêu Trâu có khả năng chống chịu $P$. capsici tốt nhất thể hiện qua tỉ lệ bệnh và chỉ số bệnh thấp hơn $(P<0,01)$ các giống tiêu còn lại, cụ thể tỉ lệ bệnh và chỉ số bệnh lần lượt là $74,1 \%$ và $73,7 \%$ sau 6 ngày lây nhiễm trong phòng thí nghiệm và $17,3 \%$ và $15,8 \%$ sau 12 ngày lây nhiễm trong nhà lưới.

\section{1. Đặt Vấn Đề}

Cây hồ tiêu (Piper nigrum L.) là cây công nghiệp nhiệt đới có giá trị kinh tế cao, lợi nhuận mang lại từ việc xuất khẩu tiêu là rất lớn. Tuy nhiên, ngành trồng tiêu trong nước đang đứng trước nhiều thách thức do thiên tai và sâu bệnh. Bệnh chết nhanh do Phytopthora capsici gây thiệt hại nghiêm trọng nhất cho ngành trồng tiêu nói riêng và ngành nông nghiệp nói chung của Việt Nam và thế giới (Anandaraj, 2000). Ở những vùng chuyên canh hồ tiêu của nước ta, bệnh đã phát triển thành ổ dịch, có nơi tỉ lệ cây chết lên đến $100 \%$, làm giảm đáng kể diện tích tiêu canh tác (Bui \& Le, 2013). Ở Indonesia, trong khoảng từ năm 1965 đến 1990, ước tính tổn thất về cây trồng do bệnh này thường dao động trong khoảng
5 - $20 \%$ và có thể lên đến $52 \%$ (Sitepu \& Mustika, 2000). Tác nhân gây bệnh trên hồ tiêu sống trong đất, tấn công vào tất cả các bộ phận của cây như rễ, thân, lá và quả (Nazeem \& ctv., 2008). Do đó, việc sử dụng các giống tiêu có khả năng chống chịu bệnh là cần thiết để quản lý bệnh và giảm thiệt hại trên hồ tiêu (Anandaraj \& Sarma, 1995).

Nghiên cứu này được thực hiện nhằm mục tiêu phân lập Phytophthora capsici gây bệnh chết nhanh và xác định khả năng chống chịu bệnh do $P$. capsici trên cây hồ tiêu. Kết quả nghiên cứu sẽ cung cấp những thông tin quan trọng về nguồn gây bệnh cũng như khả năng chống chịu bệnh chết nhanh của các giống hồ tiêu được trồng phổ biến tại Việt Nam, là cơ sở để các nhà quản lý đưa ra những biện pháp thích hợp trong quản lý bệnh trên hồ tiêu. 


\section{Vật Liệu và Phương Pháp Nghiên Cứu}

\subsection{Vật liệu}

Các giống tiêu được sử dụng gồm Vĩnh Linh, Trâu, Sẻ, Sẻ Xanh và Kuching được thu thập tại các vườn hồ tiêu tại tỉnh Bà Rịa - Vũng Tàu, Đồng Nai và Bình Dương. Hom hồ tiêu được giâm từ dây lươn và trồng trong nhà lưới 3 tháng trước khi chủng bệnh. Riêng tiêu Vĩnh Linh in vitro (nhân giống bằng phương pháp nuôi cấy mô) 5 tháng tuổi được cung cấp bởi Bộ môn Công nghệ Sinh học - Trường Đại học Nông Lâm TP.HCM. Các giống tiêu được trồng trong chậu nhựa, kích thước $23 \times 18 \mathrm{~cm}$, giá thể trồng gồm tro trấu, phân chuồng và đất sạch trộn với tỉ lệ 1:1:1. Phân bón sử dụng là NPK 20-20-15 và phun thuốc phòng ngừa bệnh Treppach Bul 607SL (probamocarb) 2 tuần/lần, ngưng phun thuốc 2 tuần trước khi chủng bệnh.

\subsection{Phương pháp nghiên cứu}

\subsubsection{Thu thập mẫu bệnh hồ tiêu}

Mẫu bệnh gồm đất, rễ, thân và lá hồ tiêu được thu thập ở các vườn hồ tiêu trên 4 năm tuổi thuộc ba tỉnh Đồng Nai, Bình Dương và Bà Rịa - Vũng Tàu, có biểu hiện bệnh chết nhanh như héo rũ một phần hay toàn cây với màu lá xanh tái, xuất hiện đốm nâu đen trên lá, rụng đốt phần thân non, rễ thối đen mềm nhũn, mạch dẫn bên trong thân biến màu từ trắng sang nâu đen chạy dọc theo thân cây (Bui \& Le, 2013). Các mẫu bệnh được bảo quản trong thùng lạnh $\left(\right.$ dưới $\left.10^{\circ} \mathrm{C}\right)$ và phân lập trong vòng 24 giờ. Đất xung quanh vùng rễ của cây hồ tiêu có biểu hiện bệnh được thu cách mặt đất $0,5-15 \mathrm{~cm}$. Ở mỗi cây có biểu hiện bệnh chết nhanh, đất được lấy ở 10 vị trí khác nhau xung quanh vùng rễ, sau đó trộn chung lại và được tính là một mẫu. Mẫu đất được chứa trong các túi nilong sạch và bảo quản trong tủ mát $\left(10-15^{0} \mathrm{C}\right)$ cho đến khi sử dụng. Danh sách nguồn mẫu thu thập và phân lập Phytophthora trình bày ở Bảng 1 .

\subsubsection{Phân lập Phytophthora từ các mẫu thu thập}

Mẫu rễ, thân và lá hồ tiêu bệnh được rửa với nước sạch và khử trùng bằng cồn $70 \%$ trong 30 giây, sau đó rửa lại bằng nước cất vô trùng và để khô trên giấy thấm. Các phần mô gần vết bệnh được cắt thành từng phần nhỏ có kích thước $2 \times$
2 mm sau đó đặt lên đĩa môi trường PDA (Potato dextrose agar) và ủ ở $25-30^{\circ} \mathrm{C}$. Quan sát hàng ngày để kiểm tra sự phát triển của hệ sợi.

Mẫu đất (50 g) cho vào hộp nhựa, sau đó thêm $100 \mathrm{~mL}$ nước cất vô trùng. Đặt một lá tiêu trưởng thành không có vết bệnh lên bề mặt và ủ ở nhiệt độ phòng. Sau 4 - 5 ngày, lá với các vết loét đặc trưng của bệnh chết nhanh được rửa dưới vòi nước, thấm khô bằng giấy lọc, khử khuẩn bề mặt bằng ethanol $70 \%$, rửa lại bằng nước cất vô trùng, cắt thành các mẫu có kích thước khoảng $0,5 \mathrm{~cm}^{2}$ và đặt lên môi trường chọn lọc, ủ trong tối ở nhiệt độ $25-30^{\circ} \mathrm{C}$ và quan sát dưới kính hiển vi sau 2 - 3 ngày (Nguyen, 2008).

Chọn các dòng P.capsici có hệ sợi màu trắng co cụm lại tạo hình hoa (Zhijun \& ctv., 2007) trên đĩa thạch để cấy chuyền sang môi trường CR $20 \%$, ủ trong tối ở $28^{0} \mathrm{C}$ trong 48 giờ. Sau đó, loại bỏ dịch CR $20 \%$, thay bằng nước cất đã hấp khử trùng và phơi sáng 36 - 48 giờ để kích thích hình thành túi bào tử. Quan sát hình dạng và kích thước túi bào tử, hình dạng và kích thước nuốm, cành sinh túi bào tử, lổ phóng thích bào tử, sự xuất hiện túi trương phồng và chlamydospore (nếu có) dưới kính hiển vi ở độ phóng đại $\mathrm{X} 10$ và $\mathrm{X} 40$ dể định danh $P$. capsici (Ho \& ctv., 1995). Khả năng gây bệnh chết nhanh trên hồ tiêu của các dòng nấm phân lập được xác định bằng phương pháp lây nhiễm nhân tạo. Dòng nấm có khả năng gây bệnh cao nhất sẽ được sử dụng cho các thí nghiệm tiếp theo.

\subsubsection{Phương pháp lây nhiễm nhân tạo}

Chuẩn bị dịch động bào tử: các dòng $P$. capsici phân lập được cấy trên môi trường CRA và ủ ở nhiệt độ phòng. Khi đường kính hệ sợi đạt $4-5$ $\mathrm{cm}$ thì lấy 10 khoanh hệ sợi có đường kính $5 \mathrm{~mm}$ ở rìa mép cấy vào đĩa petri (đường kính $90 \mathrm{~mm}$ ) có chứa $15 \mathrm{~mL}$ dung dịch CR $20 \%$ và ủ trong điều kiện tối ở $27^{\circ} \mathrm{C}$ trong 48 giờ. Hệ sợi sau đó được rửa bằng nước cất tiệt trùng 2 đến 3 lần và phơi sáng $36-48$ giờ ở nhiệt độ $27^{0} \mathrm{C}$ để kích thích hình thành túi bào tử. Thay dung dịch khoáng bằng nước cất vô trùng rồi ủ ở $10^{\circ} \mathrm{C}$ trong 30 phút để kích thích phóng bào tử động. Dịch bào tử động được đếm bằng buồng đếm hồng cầu Thomas, và được điều chỉnh đến nồng độ 106 động bào tử $/ \mathrm{mL}$ bằng nước cất vô trùng.

Lây nhiễm: Mỗi giống chọn 100 lá, dùng kim tiệt trùng tạo vết thương nhẹ trên bề mặt lá. Nhỏ $40 \mu \mathrm{L}$ dịch động bào tử của $P$. capsici đã được 
Bảng 1. Danh sách nguồn mẫu thu thập và phân lập Phytophthora

\begin{tabular}{lccc}
\hline Địa điểm thu mẫu & Vị trí lấy mẫu & Số lượng mẫu & Kí hiệu mẫu \\
\hline \multirow{2}{*}{ Huyện Phú Giáo, } & Đất & 10 & BD-Đ1 \\
Bình Dương & Lá & 5 & BD-L1 \\
& Thân & 5 & BD-T1 \\
& Rễ & 5 & BD-R1 \\
\hline \multirow{2}{*}{ Huyện Trảng Bom, } & Đất & 10 & ĐN-Đ1 \\
Đồng Nai & Lá & 8 & ĐN-L1 \\
& Thân & 3 & ĐN-T1 \\
& Rễ & 3 & ĐN-R1 \\
Huyện Xuân Lộc, & Đất & 7 & ĐN-Đ2 \\
Đồng Nai & Lá & 7 & ĐN-L1 \\
\hline \multirow{2}{*}{ Huyện Châu Đức, } & Thân & 2 & ĐN-T1 \\
Bà Rịa - Vũng Tàu & Lá & 10 & BR-Đ1 \\
& Thân & 10 & BR-L1 \\
\hline Huyện Xuyên Mộc, & Đất & 5 & BR-T1 \\
Bà Rịa - Vũng Tàu & Thân & 5 & BR-Đ2 \\
\hline
\end{tabular}

chuẩn bị như ở trên lên vết thương và quan sát vết bệnh xuất hiện trên lá.

Các chỉ tiêu theo dõi gồm:

(1) Thời gian xuất hiện vết bệnh: tính từ khi chủng đến khi có vết bệnh màu nâu đen xuất hiện trên lá.

(2) Tỉ lệ bệnh $(\%)=$ số lá bị bệnh/tổng số lá thí nghiệm) $\times 100$

(3) Chỉ số bệnh $(\%)=\sum\left\{\left[\left(\mathrm{N}_{1} \times 1\right)+\left(\mathrm{N}_{2} \times\right.\right.\right.$ $\left.\left.3)+\ldots+\left(N_{n} \times n\right)\right] / N \times n\right\} \times 100$. Trong đó, $\mathrm{N}$ là tổng số lá thí nghiệm; $\mathrm{N}_{1}, \mathrm{~N}_{2}, \ldots, \mathrm{N}_{\mathrm{n}}$ là số lá bị bệnh ở mỗi cấp $1,3,5, \ldots$, n. Các cấp bệnh trong bảng phân cấp mức độ bệnh gồm: cấp 0 là không bị bệnh, cấp 1 là khi dưới $10 \%$ diện tích lá bị bệnh, cấp 3 khi có 10 - 20\% diện tích lá bị bệnh, cấp 5 khi trên 20 - 30\% diện tích lá bị bệnh, cấp 7 khi có trên 30 - 40\% diện tích lá bị bệnh và cấp 9 khi trên $40 \%$ diện tích lá bị bệnh (QCVN 01-172:2014/BNNPTNT).

2.2.4. Đánh giá khả năng chống chịu $P$. capsici của các giống hồ tiêu trong điều kiện phòng thí nghiệm và nhà lưới

Lá của các cây hồ tiêu không có biểu hiện bệnh được cắt từ các cây hồ tiêu khỏe mạnh trồng trong nhà lưới thuộc 5 giống gồm Vĩnh Linh, Trâu, Sẻ, Sẻ Xanh và Kuching. Các lá được rửa với nước sạch và khử trùng bằng cồn $70 \%$ trong 30 giây, sau đó rửa lại bằng nước cất vô trùng và để khô trên giấy thấm. Sau đó, lá được lây nhiễm nhân tạo với dịch động bào tử của $P$. capsici gồm và ủ ở $25^{\circ} \mathrm{C}$ trong phòng thí nghiệm. Lá được nhỏ với $40 \mu \mathrm{L}$ nước cất vô trùng được dùng làm đối chứng. Thí nghiệm được lặp lại 3 lần, mỗi lần lặp lại gồm 9 lá hồ tiêu. Trong nhà lưới, chọn những cây hồ tiêu không biểu hiện bệnh gồm các giống Vĩnh Linh, Vĩnh Linh in vitro, Trâu, Sẻ và Kuching, có từ 7 - 9 lá đếm từ dưới lên. Phun dung dịch động bào tử $P$. capsici có nồng độ 106 bào tử/mL ướt đều lên lá với $25 \mathrm{~mL} / \mathrm{chậu}$. Cây được phun với nước cất vô trùng được dùng làm đối chứng. Che kín cây bằng túi nilong trong thời gian từ $4-8$ giờ. Thí nghiệm được bố trí tại nhà lưới theo kiểu khối đầy đủ hoàn toàn ngẫu nhiên (RCBD) với 3 lần lặp lại, mỗi lần lặp lại 3 chậu, mỗi chậu 1 hom. Ghi nhận thời gian xuất hiện vết bệnh, tỉ lệ bệnh và chỉ số bệnh.

\subsubsection{Phương pháp xử lý số liệu}

Số liệu được xử bằng Microsoft Excel 2010 và trắc nghiệm phân hạng Duncan's bằng chương trình xử lý thống kê SAS 9.1.

\section{Kết Quả và Thảo Luận}

\subsection{Phân lập và xác định tác nhân gây bệnh chết nhanh trên hồ tiêu}

Từ 100 mẫu gồm rễ, thân và lá cây hồ tiêu có các triệu chứng điển hình của bệnh chết nhanh và mẫu đất xung quanh cây bệnh tại các vùng 
chuyên canh hồ tiêu, đã phân lập được 08 dòng $P$. capsici (Bảng 2 ) với hệ sợi màu trắng có đường kính từ 20 - $30 \mathrm{~mm}$ và co cụm lại tạo hình hoa sau 5 ngày nuôi cấy trên môi trường CRA (Hình 1). Kết quả trên cho thấy, tỉ lệ Phytophthora phân lập được rất thấp (khoảng $8 \%$ ). Điều này có thể do trên rễ, thân và lá hồ tiêu có biểu hiện bệnh và đất xung quanh cây bệnh cùng tồn tại nhiều tác nhân gây bệnh khác nhau với biểu hiện bên ngoài tương tự nhau. Ngoài ra, các mẫu bệnh lâu ngày thường bị tạp nhiễm khiến việc phân lập gặp khó khăn.

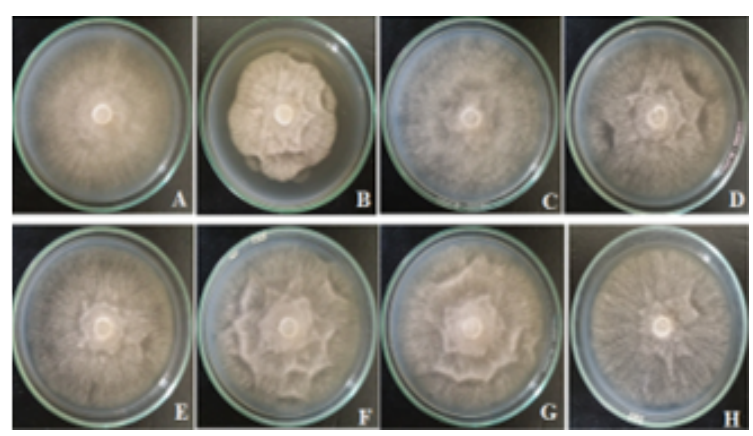

Hình 1. Hệ sợi của các dòng $P$. capsici phân lập trên môi trường $\mathrm{CRA}$ tại thời điểm 5 ngày sau cấy. (A) BD-Đ1; (B) BD-T1; (C) ĐN-Đ1;(D) ĐN-Đ2; (E) ĐN-L1; (F) BR-L1; (G) BR-Đ1; (H) BR-Đ2.

Khi lây nhiễm nhân tạo 08 dòng $P$. capsici phân lập lên lá hồ tiêu trong điều kiện phòng thí nghiệm, trên các lá đều xuất hiện các triệu chứng tương tự bệnh chết nhanh như: tại vị trí lây nhiễm lá từ màu xanh tươi chuyển sang xanh sẫm và hóa nâu đen sau 3 ngày.

Hệ sợi của tất cả các dòng $P$. capsici phân lập phù hợp với mô tả về $P$. capsici trên môi trường CRA của Le \& ctv. (2014) như có màu trắng, có dạng đồng nhất, hình ngôi sao ở tâm, mọc đều ở rìa.

Có sự khác nhau về kích thước túi bào tử của các dòng Phytophthora phân lập ở các địa điểm khác nhau. Túi bào tử của các dòng $P$. capsici phân lập ở Bình Dương có kích thước biến thiên trong khoảng $9,6-29,0 \times 7,5-14,5 \mu \mathrm{m}$ và tỉ lệ chiều dài/chiều rộng trung bình là 1,5 . Trong khi, các dòng $P$. capsici phân lập ở Đồng Nai có kích thước túi bào tử biến thiên 10,7 - 27,0 × 6,7 - 11,7 $\mu \mathrm{m}$, tỉ lệ chiều dài/chiều rộng trung bình là 1,9. Túi bào tử của các dòng phân lập ở Bà Rịa - Vũng Tàu có kích thước biến thiên 9,3 $32,5 \times 7,3-16,3 \mu \mathrm{m}$, tỉ lệ chiều dài/chiều rộng trung bình là 1,6 . Trong đó, dòng $P$. capsici kí hiệu BR-L1 phân lập từ mẫu lá tiêu bệnh ở Bà Rịa - Vũng Tàu có kích thước túi bào tử lớn nhất, trung bình $19,3 \times 10,8 \mu \mathrm{m}$, tî̉ lệ chiều dài/chiều rộng trung bình là 1,8 .

Các dòng Phytophthora phân lập có nuốm dày, không sâu, dạng nuốm cụt hay nửa bán cầu, kích thước nuốm biến thiên từ $0,8-3,3 \mu \mathrm{m}$, túi bào tử một nuốm chiếm đa số, kích thước lổ phóng thích động bào tử biến thiên từ 2,5 - 5,7 $\mu \mathrm{m}$.

Hình dạng túi bào tử của các dòng Phytopthora phân lâp được thể hiện ở Hình 2. Tất cả các dòng đều có cuống sinh túi bào tử dạng tán dù, sợi nấm chính và sợi sinh túi bào tử có kích thước tương đương nhau, hệ sợi phân vuông góc nhau. Túi bào tử có dạng hình quả lê ngược, hình trứng, trứng ngược hoặc elip đến vô định hình. Các dòng $P$. capsici phân lập không hình thành túi trương phồng, và bào tử vách dày (chlamydospore) trên đĩa thạch. Hình thái túi bào tử của các dòng $P$. capsici phân lập được phù hợp với mô tả về $P$. capsici trước đây (Zhijun \& ctv., 2007).
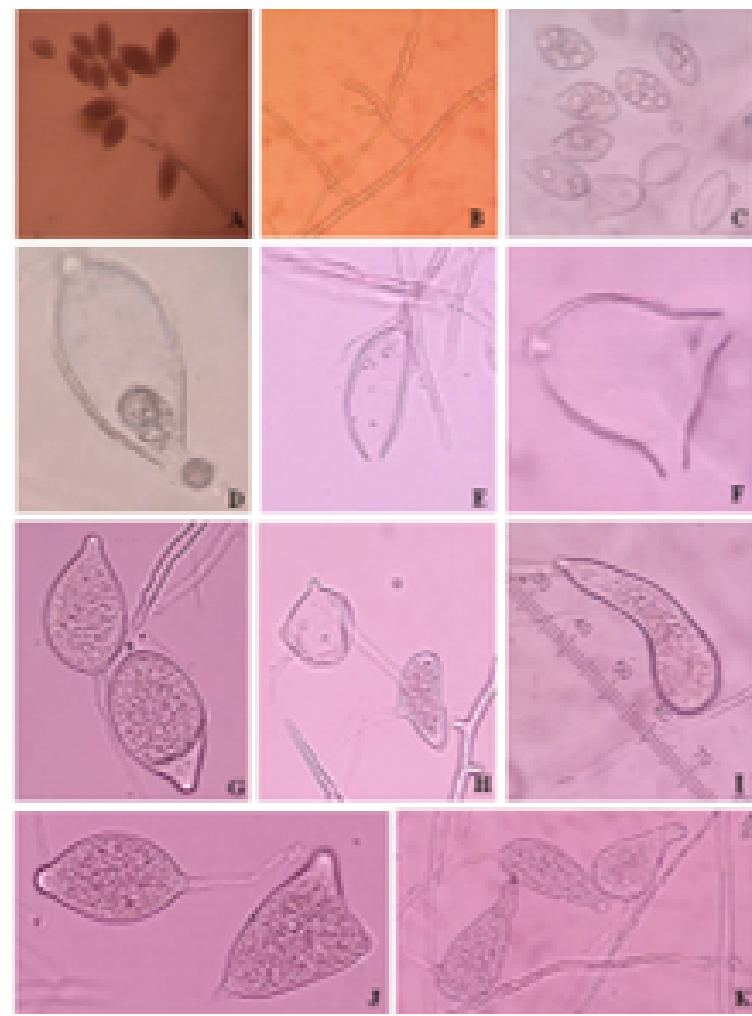

Hình 2. Hình dạng túi bào tử các dòng $P$. capsici phân lập (độ phóng đại 40X).

(A) Cành sinh túi bào tử hình tán dù; (B) Sợi nấm phân nhánh vuông góc; (C), (D) Túi bào tử phóng thích động bào tử; $(\mathrm{E}),(\mathrm{F})$ Túi bào tử với lổ phóng thích hẹp; $(\mathrm{G}),(\mathrm{H}),(\mathrm{I}),(\mathrm{J}),(\mathrm{K})$ Các dạng túi bào tử. 
Bảng 2. Kết quả phân lập Phytophthora trên các mẫu đã thu thập

\begin{tabular}{lccc}
\hline Địa điểm thu mẫu & Vị trí lấy mẫu & Số mẫu có Phytophthora & Kí hiệu mẫu \\
\hline Huyện Phú Giáo, & Đất & 1 & BD-Đ1 \\
Bình Dương & Thân & 1 & BD-T1 \\
\hline $\begin{array}{l}\text { Huyện Trảng Bom, } \\
\text { Đồng Nai }\end{array}$ & Đất & 1 & ĐN-Đ1 \\
\hline $\begin{array}{l}\text { Huyện Xuân Lộc, } \\
\text { Đồng Nai }\end{array}$ & Đất & 1 & ĐN-L1 \\
\hline $\begin{array}{l}\text { Huyện Châu Đức, } \\
\text { Bà Rịa - Vũng Tàu }\end{array}$ & Đất & 1 & Đá-Đ2 \\
\hline $\begin{array}{l}\text { Huyện Xuyên Mộc, } \\
\text { Bà Rịa - Vũng Tàu }\end{array}$ & Đất & 1 & BR-Đ1 \\
\hline
\end{tabular}

\subsection{Khả năng gây bệnh trên hồ tiêu của các dòng $P$. capsici phân lập}

Khi lây nhiễm với động bào tử của $P$. capsici, vết bệnh xuất hiện lần đầu tiên sau 18 - 19 giờ. Màu sắc và hình dạng vết bệnh trên lá hồ tiêu sau khi lây nhiễm tại thời điểm $2,3,4$ và 5 ngày được thể hiện ở Hình 3 . Vết bệnh sau 2 ngày có dạng tròn đều, chia làm hai lớp, lớp trong có màu đen, lớp ngoài màu nâu. Từ 3 ngày sau lây nhiễm, vết bệnh có xu hướng phát triển dọc theo các gân lá (nhiều nhất là đường gân chính) hướng về cuống lá và phát triển rộng ra hai bên lá. Sau khi phủ kín lá, vết bệnh có màu nâu đen, lá chuyển dần từ xanh sang vàng. Trong số 08 dòng nấm phân lập, có 03 dòng thể hiện khả năng gây bệnh mạnh nhất được xác định là các dòng có kí hiệu BR-L1, ĐN-L1 và BD-T1 được phân lập lần lượt từ mẫu lá hồ tiêu bệnh ở Bà Rịa - Vũng Tàu, Đồng Nai và mẫu thân cây hồ tiêu bệnh ở Bình Dương. Dòng nấm kí hiệu BR-L1 có mức độ gây bệnh mạnh hơn so với hai dòng còn lại.

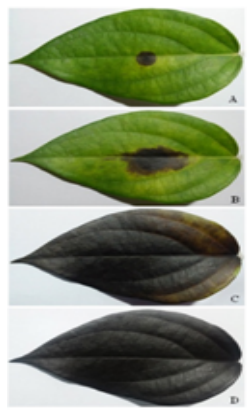

(1)

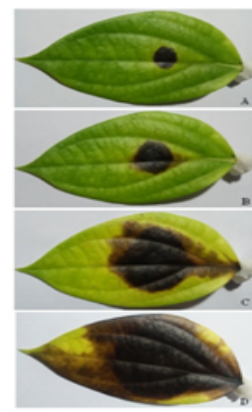

(2)

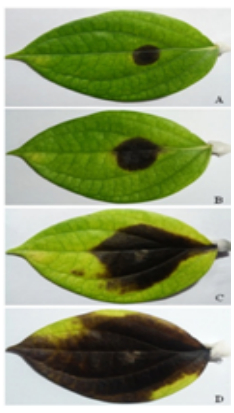

(3)
Hình 3. Triệu chứng bệnh trên lá hồ tiêu Vĩnh Linh ở các giai đoạn khác nhau.

(A) $2 \mathrm{NSLN}$; (B) $3 \mathrm{NSLN}$; (C) $4 \mathrm{NSLN}$; (D) $5 \mathrm{NSLN}$; (1) BR-L1; (2) ĐN-L1; (3) BD-T1.
3.3. Khả năng chống chịu $P$. capsici của hồ tiêu trong điều kiện phòng thí nghiệm và nhà lưới

Nhằm đánh giá khả năng chống chịu bệnh chết nhanh do $P$. capsici của các giống hồ tiêu được trồng phổ biến ở Việt Nam, động bào tử của dòng P.capsici phân lập có mức độ gây bệnh cao nhất kí hiệu BR-L1 được lây nhiễm lên lá của năm giống Vĩnh Linh, Sẻ, Trâu, Xanh và Kuching trong điều kiện phòng thí nghiệm và nhà lưới. Khả năng chống chịu bệnh của hồ tiêu được thể hiện qua tỉ lệ bệnh và chỉ số bệnh. Trong điều kiện phòng thí nghiệm, tỉ lệ bệnh và chỉ số bệnh ở các lá hồ tiêu được lây nhiễm sau $2,3,4,5$ và 6 ngày được thể hiện ở Bảng 3 và Bảng 4 . Vết bệnh phát triển từ vị trí gây vết thương tăng dần qua các ngày (Hình 4). Tại thời điểm 2 ngày sau lây nhiễm, cả năm giống tiêu đều xuất hiện triệu chứng bệnh ban đầu. Trong đó, tỉ lệ bệnh và chỉ số bệnh cao nhất (lần lượt là $88,89 \%$ và $11,11 \%$ ) ở giống tiêu Sẻ và thấp nhất (lần lượt là $37,04 \%$ và $4,12 \%$ ) ở giống tiêu Trâu, khác biệt có ý nghĩa so với các giống tiêu còn lại. Như vậy, trong năm giống tiêu thử nghiệm, tiêu Sẻ thể hiện khả năng chống chịu với $P$. capsici thấp nhất. Sau khi xâm nhập vào vị trí gây vết thương, động bào tử $P$. capsici tiết độc chất (gồm các enzyme như cutinase, capsaicin) gây hoại tử mô và tế bào làm lá hồ tiêu bị chết nên có màu nâu hoặc đen. Sau 6 ngày lây nhiễm, toàn bộ lá hồ tiêu giống Vĩnh Linh, Sẻ và Kuching đều chuyển sang màu đen với tỉ lệ bệnh $100 \%$ và chỉ số bệnh 99,69\%. Lá tiêu Trâu thể hiện khả năng chống chịu $P$. capsici tốt nhất với tỉ lệ bệnh $74,07 \%$ và chỉ số bệnh $73,66 \%$, khác biệt có ý nghĩa so với các giống tiêu còn lại $(P<0,01)$. Khả năng chống chịu bệnh do Phytophthora trên hồ tiêu đã được chứng minh có liên quan đến hoạt 
Bảng 3. Tỉ lệ bệnh của các giống hồ tiêu khi được lây nhiễm trong phòng thí nghiệm

\begin{tabular}{lccccc}
\hline \multirow{2}{*}{ Giống } & \multicolumn{5}{c}{ Tỉ lệ lá bệnh (\%) sau các ngày lây nhiễm } \\
\cline { 2 - 6 } & 2 NSLN & 3 NSLN & 4 NSLN & 5 NSLN & 6 NSLN \\
\hline Vĩnh Linh & $77,78^{\text {ab }}$ & $100,00^{\mathrm{a}}$ & $100,00^{\mathrm{a}}$ & $100,00^{\mathrm{a}}$ & $100,00^{\mathrm{a}}$ \\
Sẻ & $88,89^{\mathrm{a}}$ & $100,00^{\mathrm{a}}$ & $100,00^{\mathrm{a}}$ & $100,00^{\mathrm{a}}$ & $100,00^{\mathrm{a}}$ \\
Xanh & $48,15^{\mathrm{bc}}$ & $85,19^{\mathrm{b}}$ & $92,59^{\mathrm{a}}$ & $96,30^{\mathrm{a}}$ & $96,30^{\mathrm{a}}$ \\
Trâu & $37,04^{\mathrm{c}}$ & $70,37^{\mathrm{b}}$ & $74,07^{\mathrm{b}}$ & $74,07^{\mathrm{b}}$ & $74,07^{\mathrm{b}}$ \\
Kuching & $85,19^{\mathrm{ab}}$ & $96,30^{\mathrm{a}}$ & $100,00^{\mathrm{a}}$ & $100,00^{\mathrm{a}}$ & $100,00^{\mathrm{a}}$ \\
\hline CV (\%) & 14,70 & 7,24 & 8,91 & 6,25 & 6,25 \\
\hline Mức ý nghĩa & $* *$ & $* *$ & $* *$ & $* *$ & $* *$ \\
\hline
\end{tabular}

a-c Số liệu đã được chuyển đổi sang dạng $\arcsin \left(\mathrm{x}^{\frac{1}{2}}\right)$ trước khi xử lý thống kê. Trong cùng một cột, các giá trị có kí tự theo sau giống nhau không có sự khác biệt về mặt thống kê. *** khác biệt có ý nghĩa ở mức $P \leq 0,01$; NSLN: ngày sau lây nhiềm.

Bảng 4. Chỉ số bệnh của các giống hồ tiêu khi được lây nhiễm trong phòng thí nghiệm

\begin{tabular}{lccccc}
\hline \multirow{2}{*}{ Giống } & \multicolumn{5}{c}{ Chỉ số bệnh (\%) trên lá hồ tiêu sau các ngày lây nhiễm } \\
\cline { 2 - 6 } & 2 NSLN & 3 NSLN & 4 NSLN & 5 NSLN & 6 NSLN \\
\hline Vĩnh Linh & $8,23^{\mathrm{ab}}$ & $35,80^{\mathrm{a}}$ & $81,07^{\mathrm{a}}$ & $98,15^{\mathrm{a}}$ & $99,69^{\mathrm{a}}$ \\
Sẻ & $11,11^{\mathrm{a}}$ & $57,20^{\mathrm{a}}$ & $76,13^{\mathrm{a}}$ & $98,97^{\mathrm{a}}$ & $99,69^{\mathrm{a}}$ \\
Xanh & $5,35^{\mathrm{bc}}$ & $20,16^{\mathrm{bc}}$ & $39,92^{\mathrm{b}}$ & $69,96^{\mathrm{b}}$ & $88,48^{\mathrm{b}}$ \\
Trâu & $4,12^{\mathrm{c}}$ & $13,58^{\mathrm{c}}$ & $29,63^{\mathrm{b}}$ & $49,79^{\mathrm{c}}$ & $73,66^{\mathrm{c}}$ \\
Kuching & $11,11^{\mathrm{a}}$ & $45,68^{\mathrm{a}}$ & $96,50^{\mathrm{a}}$ & $98,15^{\mathrm{a}}$ & $99,69^{\mathrm{a}}$ \\
\hline CV (\%) & 4,50 & 6,77 & 8,24 & 4,08 & 3,15 \\
\hline Mức ý nghĩa & $* *$ & $* *$ & $* *$ & $* *$ & $* *$ \\
\hline
\end{tabular}

a-c Số liệu đã được chuyển đổi sang dạng $\arcsin \left(\mathrm{x}^{\frac{1}{2}}\right)$ trước khi xử lý thống kê. Trong cùng một cột, các giá trị có kí tự theo sau giống nhau không có sự khác biệt về mặt thống kê. **: khác biệt có ý nghĩa ở mức $P \leq 0,01$; NSLN: ngày sau lây nhiễm.

tính enzyme $\beta-1,3$ glucanase trong cây (Nazeem \& ctv., 2008). Kết quả có thể được giải thích là do hoạt tính $\beta-1,3$ glucanase của giống tiêu Trâu cao hơn (Ton \& ctv., 2018) nên thể hiện khả năng chống chịu tốt hơn so với các giống tiêu khác trong thí nghiệm.

Trong nhà lưới, triệu chứng bệnh xuất hiện trên lá cả năm giống hồ tiêu sau 3 ngày lây nhiễm. Triệu chứng bệnh rất đa dạng, vết bệnh ở chóp lá, cuống lá, mép lá, giữa lá hoặc toàn bộ phiến lá, làm cho lá bị đen dọc theo gân lá, lá bị héo và treo lơ lững trên dây tiêu. Tỉ lệ bệnh và chỉ số bệnh sau $3,5,7,9$ và 12 ngày lây nhiễm được trình bày ở Bảng 5 và Bảng 6 .

Sau 5 ngày lây nhiễm, bệnh phát triển rất nhanh, gây hại nặng và đồng loạt trên cả năm giống tiêu, bệnh tấn công trên hầu hết các bộ phận của cây, một số cây có biểu hiện thối thân, gãy ngọn. Thời điểm từ 9 đến 12 ngày sau lây nhiễm, cây hồ tiêu có biểu hiện bị héo rũ toàn thân, cuống lá và thân bị thối đen và gãy ngang. Giống tiêu Trâu tiếp tục cho thấy khả năng chống

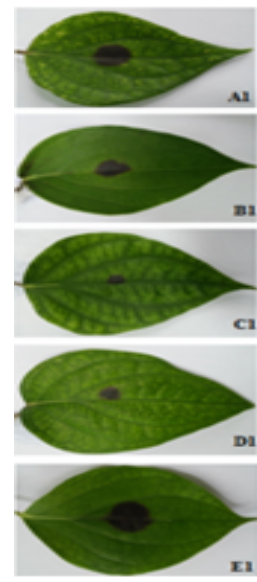

(1)

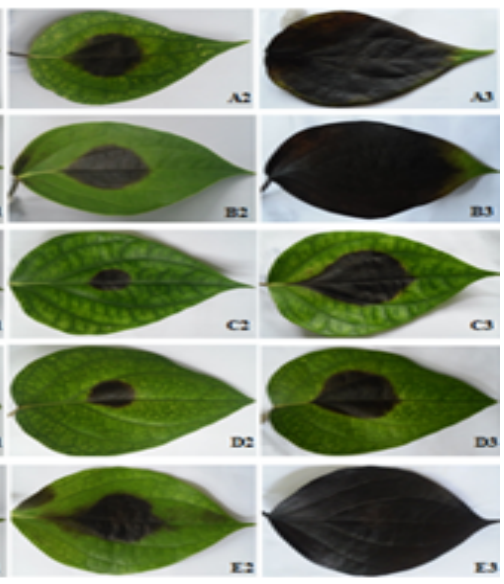

(2)
(3)
Hình 4. Hình dạng vết bệnh do $P$. capsici gây ra trên lá một số giống hồ tiêu tại các thời điểm khác nhau.

(1) 2 ngày sau lây nhiễm; (2) 3 ngày sau lây nhiễm; (3) 5 ngày sau lây nhiễm. (A) Tiêu Vĩnh Linh; (B) Tiêu Sẻ; (C) Tiêu Xanh; (D) Tiêu Trâu; (E) Tiêu Kuching. 
Bảng 5. Tỉ lệ bệnh của các giống hồ tiêu khi được lây nhiễm trong nhà lưới

\begin{tabular}{|c|c|c|c|c|c|}
\hline \multirow{2}{*}{ Giống } & \multicolumn{5}{|c|}{ Tỉ lệ lá bệnh (\%) sau các ngày lây nhiễm } \\
\hline & $3 \mathrm{NSLN}$ & 5 NSLN & $7 \mathrm{NSLN}$ & 9 NSLN & $12 \mathrm{NSLN}$ \\
\hline Vĩnh Linh & 3,0 & $14,4^{\mathrm{a}}$ & $23,2^{\mathrm{a}}$ & $24,5^{\mathrm{b}}$ & $30,5^{\mathrm{b}}$ \\
\hline Kuching & 2,9 & $13,3^{\mathrm{a}}$ & $22,7^{\mathrm{a}}$ & $29,0^{\mathrm{a}}$ & $37,4^{\mathrm{a}}$ \\
\hline Trâu & 2,8 & $11,6^{\mathrm{b}}$ & $14,9^{\mathrm{c}}$ & $16,0^{\mathrm{d}}$ & $17,3^{\mathrm{d}}$ \\
\hline Vĩnh Linh in vitro & 2,1 & $14,6^{\mathrm{a}}$ & $15,9^{\mathrm{bc}}$ & $19,5^{\mathrm{c}}$ & $20,7^{\mathrm{dc}}$ \\
\hline Sẻ & 2,1 & $12,9^{\mathrm{ab}}$ & $17,9^{\mathrm{a}}$ & $19,3^{\mathrm{c}}$ & $23,2^{\mathrm{c}}$ \\
\hline $\mathrm{CV}(\%)$ & 26,1 & 7,3 & 7,8 & 7,6 & 7,9 \\
\hline Mức ý nghĩa & ns & $*$ & $*$ & $*$ & $*$ \\
\hline
\end{tabular}

Bảng 6. Chỉ số bệnh của các giống hồ tiêu khi được lây nhiễm trong nhà lưới

\begin{tabular}{|c|c|c|c|c|c|}
\hline \multirow{2}{*}{ Giống } & \multicolumn{5}{|c|}{ Chỉ số bệnh (\%) lá hồ tiêu sau các ngày lây nhiễm } \\
\hline & $3 \mathrm{NSLN}$ & $5 \mathrm{NSLN}$ & 7 NSLN & 9 NSLN & $12 \mathrm{NSLN}$ \\
\hline Vĩnh Linh & 1,8 & $8,1^{\mathrm{a}}$ & $14,3^{\mathrm{a}}$ & $18,2^{\mathrm{a}}$ & $26,4^{\mathrm{a}}$ \\
\hline Kuching & 1,5 & $7,9^{\mathrm{a}}$ & $16,3^{\mathrm{a}}$ & $20,0^{\mathrm{a}}$ & $26,7^{\mathrm{a}}$ \\
\hline Trâu & 1,5 & $5,5^{\mathrm{b}}$ & $11,7^{\mathrm{b}}$ & $15,3^{\mathrm{b}}$ & $15,8^{\mathrm{c}}$ \\
\hline Vĩnh Linh in vitro & 1,3 & $4,3^{\mathrm{b}}$ & $10,3^{\mathrm{b}}$ & $14,9^{\mathrm{b}}$ & $17,8^{\mathrm{cb}}$ \\
\hline Sẻ & 1,3 & $5,6^{\mathrm{b}}$ & $11,3^{b}$ & $15,5^{\mathrm{b}}$ & $19,4^{\mathrm{b}}$ \\
\hline $\mathrm{CV}(\%)$ & 18,5 & 10,8 & 8,9 & 6,3 & 6,5 \\
\hline Mức ý nghĩa & ns & $*$ & $*$ & $*$ & $*$ \\
\hline
\end{tabular}

chịu tốt đối với $P$. capsici, khác biệt có ý nghĩa so với các giống tiêu khác $(P<0,05)$.

Như vậy, khi lây nhiễm ở điều kiện phòng thí nghiệm và nhà lưới, giống tiêu Trâu thể hiện khả năng chống chịu $P$. capsici tốt hơn so với các giống còn lại.

\section{Kết Luận}

Từ 100 mẫu gồm rễ, thân và lá hồ tiêu có biểu hiện bệnh chết nhanh và đất xung quanh cây bệnh, đã phân lập được tám dòng được xác định là $P$. capsici. Các dòng này đều thể hiện khả năng gây bệnh chết nhanh trên hồ tiêu. Trong đó, dòng có kí hiệu BR-L1 được phân lập từ lá hồ tiêu bệnh thu thập ở Bà Rịa - Vũng Tàu có khả năng gây bệnh cao nhất.

Sau khi lây nhiễm động bào tử $P$. capsici trên các giống hồ tiêu gồm Vĩnh Linh, Sẻ, Xanh, Trâu và Kuching trong điều kiện phòng thí nghiệm và điều kiện nhà lưới, giống tiêu Trâu thể hiện khả năng chống chịu bệnh do $P$. capsici cao nhất với tỉ lệ bệnh và chỉ số bệnh thấp nhất trong số các giống hồ tiêu thí nghiệm. Cần có những nghiên cứu về cơ chế và gene quy định tính kháng $P$. capsici của các giống tiêu nhằm phục vụ công tác chọn tạo giống hồ tiêu có khả năng kháng lại các tác nhân gây bệnh.

\section{Tài Liệu Tham Khảo (References)}

Anandaraj, M. (2000). Diseases of black pepper. In Ravindran, P. N. (Ed.). Black pepper (Piper nigrum) (239-267). Amsterdam, The Netherlands: Harwood Academic Publishers.

Anandaraj, M., \& Sarma, Y. R. (1995). Diseases of black pepper (Piper nigrum L.) and their management. Journal of Spices Aromatic Crops 4(1), 17-23.

Bui, T. C., \& Le, D. D. (2013). Pepper plant, diseases and preventive methods. Ha Noi, Vietnam: Agricultural Publishing House.

Ho, H. H., Anm, P. J., \& Chang, H. S. (1995). The genus Phytophthora in Taiwan. Academia Sinica, Taipei, Taiwan: Institute of Botany.

Le, L. Q., Nguyen, U. H. P., \& Phan, G. H. (2014). Study on the antifungal effect of silver nano particlechitosan prepared by irradiation method on Phytophthora capsici causing the blight disease on pepper plant. Academia Journal of Biology 36(1se), 152-157. 
Nazeem, P. A., Achuthan, C. R., Babu, T. D., Parab, G. V., Girija, D., Keshavachandran, R., \& Samiyappan, R. (2008). Expression of pathogenesis related proteins in black pepper (Piper nigrum L.) in relation to Phytophthora foot rot disease. Journal of Tropical Agriculture 46(1-2), 45-51.

Nguyen, T. V. (2008). Baiting and monitoring propagules of pathogen causing Phytophthora foot rot of black pepper in soil. Journal of Plant Protection 4, 13-26.

Sitepu, D., \& Mustika, I. (2000). Disease of black pepper and their management in Indonesia. In Ravindran, P.N. (Ed.). Black pepper (Piper nigrum) (297-299). Amsterdam, The Netherlands: Harwood Academic Publishers.
Ton, A. T., Ton, L. B., Nguyen, V. P., Bien T. T. L., To, T. T. N., \& Le, D. D. (2018). Expression of proteins related to Phytophthora capsici tolerance in black pepper (Piper nigrum L.). International Journal of Agriculture Innovations and Research 6(4), 2319-1473.

Zhijun, L., Weiping, L., Jinrong, Z., \& Lei, J. (2007). Isolation and identification of Phytophthora capsici in Guangdong province and measurement of their pathogenicity and physiological race differentiation. Frontiers of Agriculture in China 1(4), 377-381. 